\title{
Brake performance assessment of traction vehicles - Research and exploitation aspects
}

\section{Ocena skuteczności hamulca zespołów trakcyjnych - Zagadnienia badawcze i eksploatacyjne}

Transport of passengers is carried out essentially using two types of vehicles: classic trains composed of a locomotive pulling passenger wagons or traction units (or multiple units). Both new and modernized rail vehicles must be subjected to, among others, brake system tests when being placed into service. The purpose of such tests is to check the correct operation of the brake system and to determine the actual brake performance.

The method of determining the passenger wagon brake performance differs from the similar method for the train set, although the braking performance of both types of vehicles is eventually presented in the form of two parameters: the value of brake mass $B$ expressed in tons and the percentage of braked mass $\lambda$, i.e. the ratio of braked mass to vehicle total mass, expressed as a percentage. The values of $B$ and $\lambda$ determined from the tests describing the brake performance serve to assess the brake performance of the train in operation, while railway traffic safety relies significantly on the correct understanding of their nature and their use. Unfortunately, it was observed that individual carriers interpret these values in different ways and describe them in various ways on vehicles that are ultimately operated on the same infrastructure.

The article presents a proposal of a new, original, unified and transparent method of describing brake performance for electric multiple units, as well as its interpretation and application in railway operations, developed in the Brakes Workshop of the Railway Institute.

Przewozy pasażerskie realizowane sq $z$ wykorzystaniem zasadniczo dwóch rodzajów pojazdów: klasycznych pociagów złożonych z lokomotywy i ciagniętych przez niq wagonów pasażerskich lub zespołów trakcyjnych (ewentualnie pociagów zespołowych).

Zarówno nowe jak i modernizowane pojazdy szynowe w trakcie procesu dopuszczenia do eksploatacji musza zostać poddane m.in. badaniom uktadu hamulcowego. Celem takich badań jest sprawdzenie poprawności działania tego układu oraz wyznaczenie rzeczywistej skuteczności hamulca.

Metoda wyznaczenia skuteczności hamulca wagonu pasażerskiego różni się od analogicznej metody dla zespolu trakcyjnego, mimo iż ostatecznie skuteczność hamulca obu rodzajów pojazdów przedstawiana jest $w$ postaci dwóch parametrów: wyrażanej $w$ tonach wartości masy hamujqcej $B$ i procentu masy hamujacej $\lambda$, czyli stosunku masy hamujacej do masy pojazdu, wyrażonego w procentach.

Wyznaczone $w$ rezultacie badań wartości $B$ i $\lambda$ opisujace skuteczność hamulca stuża $w$ trakcie eksploatacji pojazdów ocenie skuteczności hamulca pociagu, a właściwe zrozumienie ich istoty i prawidlowy sposób postugiwania się nimi maja decydujace znaczenie dla bezpieczeństwa ruchu kolejowego. Niestety zaobserwowano, że poszczególni przewoźnicy na różny sposób interpretuja te wartości $i$ w różny sposób opisuja je na pojazdach, które ostatecznie eksploatowane sq na tej samej infrastrukturW artykule przedstawiono opracowana w Pracowni Hamulców Instytutu Kolejnictwa propozycję nowego, oryginalnego, ujednoliconego i przejrzystego sposobu opisywania skuteczności hamulca na elektrycznych zespołach trakcyjnych oraz jej interpretacji i stosowania w praktyce kolejowej. 


\section{INTRODUCTION}

One of the specific features of the railway is the ability to compose trainsets from various railway vehicles, often significantly different from one another, both as to their destination and construction.

Regardless of which vehicles the trainset has been set up (they can be freight wagons, passenger cars, inactive locomotives, special purpose vehicles and many others) and what is absolutely necessary is the need to estimate the brake performance of the trainset as a whole. The method of calculating the train brake performance must be unambiguous and must allow making a quick decision to permit the train to enter the railway route (transporting the train) after checking that the brake meets the performance requirements.

\section{PARAMETERS DESCRIBING THE BRAKE PERFORMANCE}

The most important parameters that can be used to assess the performance of a railway vehicle brake are:

$$
\begin{aligned}
& \text { - } \text { stopping distance } s[\mathrm{~m}], \\
& -\quad \text { deceleration } a\left[\mathrm{~m} / \mathrm{s}^{2}\right], \\
& -\quad \text { braking mass } B[\mathrm{t}], \\
& -\quad \text { braking mass percentage } \lambda[-] .
\end{aligned}
$$

The stopping distance is a parameter that allows for precise and understandable, even for those who are not familiar with rail traffic operations on an everyday basis, to evaluate the brake performance. For obvious reasons, however, it is not possible to explicitly describe the vehicle brake performance with this single parameter, because the stopping distance depends on the initial speed at which the braking was initiated. For this reason, this value is completely unusable for assessing the brake performance of a train.

The deceleration is a more difficult figure to interpret than the stopping distance, but the clear advantage of this parameter is that it can already be easily assigned to a specific vehicle and to some extent does not depend on the initial vehicle speed. Practical use has shown, however, that using it in the classical organization of rail transport, this parameter is not applicable to the train brake performance assessment on the larger scale.

The parameters describing the brake performance as accepted for practical use in the rail conditions are the braking mass $\mathrm{B}$ and the percentage of braking mass $\lambda$. They are immeasurable quantities, and their calculation relies on empirical formulas developed based on extensive and long-term research.

\section{PRACTICAL APPLICATIONS}

The method used for calculating the trainset brake performance based on the knowledge of the brake performance of the vehicles out of which it has been composed requires the knowledge of the following data for each of the vehicles in the trainset:

\section{WSTEP}

Jedną ze specyficznych cech kolei jest możliwość konfigurowania pociagów z różnych pojazdów kolejowych, niejednokrotnie w sposób istotny różniących się od siebie zarówno co do przeznaczenia jak i konstrukcji.

Bez względu jednak na to $z$ jakich pojazdów skonfigurowany został skład pociagu (mogą to być wagony towarowe, pasażerskie, lokomotywy w stanie nieczynnym, maszyny specjalnego przeznaczenia i wiele innych) i jaka jest ich liczba absolutnie niezbędna jest konieczność oszacowania skuteczności hamulca pociagu. Metoda obliczania skuteczności hamulca pociagu musi być jednoznaczna i musi umożliwiać szybkie podjęcie decyzji co do możliwości wjazdu pociagu na szlak kolejowy (wyprawienia pociagu) po sprawdzeniu spełnienia przez jego hamulec wymagań dotyczących skuteczności.

\section{PARAMETRY OPISUJĄCE SKUTECZ- NOŚĆ HAMULCA}

Najważniejszymi z wielkości, które mogą służyć do oceny skuteczności hamulca pojazdu kolejowego są:

- droga hamowania $s[\mathrm{~m}]$,

- opóźnienie $a\left[\mathrm{~m} / \mathrm{s}^{2}\right]$,

- masa hamująca $B[\mathrm{t}]$,

- procent masy hamującej $\lambda[-]$.

Droga hamowania jest wielkością, która pozwala w sposób precyzyjny i zrozumiały, nawet dla osób nie związanych na co dzień z prowadzeniem ruchu kolejowego, ocenić skuteczność hamulca. $Z$ oczywistych względów nie jest możliwe jednak jednoznaczne opisanie skuteczności hamulca pojazdu za pomocą tego parametru, ponieważ droga hamowania zależy od prędkości początkowej przy jakiej wdrożono hamowanie. $Z$ tego też powodu wielkość ta jest całkowicie nieprzydatna do oceny skuteczności hamulca pociągu.

Opóźnienie jest wielkością trudniejszą w interpretacji od drogi hamowania, niemniej niewątpliwą jego zaletą jest to, że może już być jednoznacznie przypisane do konkretnego pojazdu i w pewnym zakresie nie zależy od prędkości początkowej. Praktyka wykazała jednak, że w zastosowaniu do klasycznej organizacji przewozów kolejowych parametr ten nie jest możliwy do zastosowania do oceny skuteczności hamulca pociagu.

Przyjętymi do praktycznego zastosowania w warunkach kolejowych parametrami opisującymi skuteczność hamulca są masa hamująca $B$ i procent masy hamującej $\lambda$. Są one niemierzalnymi wielkościami, a do ich obliczeń stosowane są wzory empiryczne opracowane na podstawie obszernych i wieloletnich badań.

\section{PRAKTYCZNE ZASTOSOWANIE}

Stosowana w praktyce metoda obliczania skuteczności hamulca pociagu na podstawie znajomości sku- 
$B_{i}[\mathrm{t}] \quad$ - braking mass of the $\mathrm{i}$-th vehicle

$m_{i}[\mathrm{t}] \quad$ - the so-called gross mass of the $\mathrm{i}$-th vehicle (total mass).

The biggest advantage of this method of assessing brake performance is its simplicity and the ability to do calculations even without a calculator.

The brake performance calculations and assessment for the trainset are based on the methodology described in the UIC 544-1 [1], using the formulas (1), (2), (3) in the following stages:

I. Reading the values of braking masses of individual vehicles included in the trainset and calculating the braking mass value of the whole trainset:

$$
B_{\text {poc }}=\sum_{i=1}^{n} B_{i}
$$

where:

$B_{p o c}[\mathrm{t}]$ - total trainset braking mass,

$i[-]$ - vehicle number in the trainset,

$n[-]$ - number of vehicles in the trainset.

II. Reading the value of total masses of individual vehicles included in the trainset and calculating the trainset total mass:

$$
m_{\text {poc }}=\sum_{i=1}^{n} m_{i}
$$

where:

$$
m_{p o c}[\mathrm{t}] \text { - total mass of the trainset. }
$$

III. Calculating the trainset braking mass percentage:

where:

$$
\lambda_{\text {poc }}=\frac{B_{p o c}}{m_{p o c}} \cdot 100 \%
$$

$$
\lambda_{p o c}[\mathrm{t}] \text { - train braking mass percentage. }
$$

The value of train braking mass percentage calculated using the formula (3) serves the person delegated for the task (most often it is an employee of the infrastructure manager) to check whether the brake performance of the train meets the requirements for the railway route through which the train is to travel. These requirements are listed in the so-called braking tables - which describe the required percentage of braking mass depending on the vehicle speed, the measured track inclination, and the maximum permitted stopping distance, and are included in the regulations of the railway operation director or infrastructure manager.

If the percentage of the train braking mass is not below the required value, it is possible to permit the train to travel with its maximum permitted speed. Otherwise, it is either impossible or requires limiting the maximum speed of the train on a given track section.

\section{DETERMINING THE „B” AND,$\lambda "$ PARAMETERS FOR RAIL VEHICLES}

The values of the braking mass $\mathrm{B}$ and the braking teczności hamulca pojazdów, z których został skonfigurowany, wymaga by osoba oceniająca skuteczność hamulca znała następujące dane każdego z pojazdów w pociagu:

$B_{i}[\mathrm{t}] \quad$ - masa hamująca i-tego pojazdu,

$m_{i}[\mathrm{t}] \quad$ - tzw. masa brutto i-tego pojazdu (masa całkowita).

Największą zaletą tej metody oceny skuteczności hamulca jest jej prostota i możliwość wykonania obliczeń nawet bez kalkulatora.

Obliczenia i ocena skuteczności hamulca pociagu odbywają się w oparciu o metodykę opisaną w karcie UIC 544-1 [1], z wykorzystaniem wzorów (1), (2), (3) w następujących etapach:

I. Odczytanie wartości mas hamujących poszczególnych pojazdów wchodzących w skład pociagu i obliczenie wartości masy hamującej całego pociagu:

gdzie:

$$
B_{\text {poc }}=\sum_{i=1}^{n} B_{i}
$$

$B_{p o c}[\mathrm{t}]$ - masa hamująca pociagu

$i[-]$ - numer pojazdu w pociagu

$n[-]$ - liczba pojazdów w pociagu.

II. Odczytanie wartości mas całkowitych poszczególnych pojazdów wchodzących w skład pociagu i obliczenie wartości masy całkowitej całego pociagu:

$$
m_{\text {poc }}=\sum_{i=1}^{n} m_{i}
$$

gdzie:

$$
m_{p o c}[\mathrm{t}] \text { - masa całkowita pociagu. }
$$

III. Obliczenie procentu masy hamującej pocią$\mathrm{gu}$ :

$$
\lambda_{\text {poc }}=\frac{B_{p o c}}{m_{p o c}} \cdot 100 \%
$$

gdzie:

$\lambda_{p o c}[\mathrm{t}]$ - procent masy hamującej pociągu.

Obliczona w oparciu o wzór (3) wartość procentu masy hamującej pociągu służy osobie odpowiedzialnej (najczęściej jest nią pracownik zarządcy infrastruktury) do sprawdzenia, czy skuteczność hamulca pociagu spełnia wymagania odnoszące się do szlaku kolejowego, na który ma być skierowany pociagg. Wymagania te zawarte są w tzw. tabelach hamowania - są to zawarte w przepisach przewoźnika kolejowego lub zarządcy infrastruktury tabele wymaganych procentów masy hamującej w zależności od rozkładowej prędkości jazdy pociagu, miarodajnego pochylenia toru oraz maksymalnej dopuszczalnej drogi hamowania.

Jeżeli procent masy hamującej pociagu jest nie mniejszy niż wymagany, możliwe jest wyprawienie pociągu na szlak z maksymalną dozwoloną prędkością. W przeciwnym wypadku jest to niemożliwe lub wymaga ograniczenia maksymalnej prędkości pociągu na tym szlaku. 
mass percentage $\lambda$ of the train may be calculated theoretically or determined based on the results of tests carried out on the vehicle. Details of the calculation methodology (for the rail vehicles discussed in this article) are described in the provisions of the International UIC Railway Union [1], the European Commission Regulation [2] and the European Standard [3].

The results of theoretical calculations are used for the initial assessment of brake performance enabling the final selection of brake system components and its parameters to be regulated.

The only reliable method of determining the vehicle braking mass and the braking mass percentage is to carry out these tests. Only in this way can the determined values be later used in the practical assessment of the braking performance of the train during normal operation.

This article discusses problems related to the braking performance assessment of traction units, however it is worth recalling briefly that the motion brake tests (i.e. tests whose aim is to determine the parameters describing brake performance) are performed as follows:

- for freight and passenger wagons by means of sudden braking of the tested vehicle after detaching it while driving away from the measuring train

- for traction vehicles (including locomotives and traction units) by means of sudden or full braking in the same way as during normal operation.

The basic directly measured quantities used to determine the braking mass percentage are:

- stopping distance

- initial braking vehicle speed.

Moreover, it is necessary to additionally measure a number of other quantities, including: pressure in brake cylinders, brake cylinders filling time, wheel diameter.

The purpose of this article is not a detailed discussion of the methodology of determining the braking mass percentage, however, to realize the scope and time demand of brake motion tests, it is worth mentioning that for example the most popular electric traction units in Poland equipped with pneumatic, electro-pneumatic and electrodynamic brakes and only for the brake setting "R" tests are performed in three engine load states and for five initial vehicle braking speeds in the range of $30 \div 160$ $\mathrm{km} / \mathrm{h}$. During such tests, approximately 350 braking tests are carried out, and the time required to perform these tests is $15 \div 20$ working days.

As a result of the research the following values are obtained:

\section{WYZNACZANIE WARTOŚCI „B” I , $\lambda$ " POJAZDÓW}

Wartości masy hamującej $B$ i procentu masy hamującej $\lambda$ pojazdu kolejowego mogą być obliczone teoretycznie lub wyznaczone na podstawie wyników przeprowadzonych badań pojazdu. Szczegóły dotyczące metodyki obliczeń (dla omawianych w niniejszym artykule zespołów trakcyjnych) zawarte są w przepisach Międzynarodowego Związku Kolei UIC [1], rozporządzeniu Komisji Europejskiej [2] i Normie Europejskiej [3].

Wyniki obliczeń teoretycznych służą do wstępnej oceny skuteczności hamulca umożliwiającej ostateczny dobór komponentów układu hamulcowego i jego parametrów podlegających regulacji.

Jedyną miarodajną metodą wyznaczenia masy hamującej i procentu masy hamującej pojazdu jest przeprowadzenie badań. Tylko w ten sposób wyznaczone wartości mogą później służyć w praktycznej ocenie skuteczności hamulca pociagu podczas normalnej eksploatacji.

Niniejszy artykuł dotyczy problemów związanych z oceną skuteczności hamulca zespołów trakcyjnych, jednakże warto w skrócie przypomnieć, że badania ruchowe hamulca (czyli badania których celem jest wyznaczenie parametrów opisujących skuteczność hamulca) wykonywane są w następujący sposób:

- dla wagonów towarowych i pasażerskich poprzez hamowanie nagłe badanego pojazdu po odczepieniu go podczas jazdy od pociagu pomiarowego

- dla pojazdów trakcyjnych (w tym lokomotyw i zespołów trakcyjnych) poprzez wykonanie hamowania nagłego lub pełnego $\mathrm{w}$ identyczny sposób jak podczas normalnej eksploatacji.

Podstawowymi bezpośrednio mierzonymi wielkościami służącymi do wyznaczania procentu masy hamującej są:

- droga hamowania

- początkowa prędkość hamowania.

Ponadto niezbędny jest dodatkowo pomiar szeregu innych wielkości, m.in.: ciśnienia w cylindrach hamulcowych, czasu napełniania cylindrów hamulcowych, średnicy kół.

Szczegółowe omówienie metodyki wyznaczania procentu masy hamującej nie jest celem tego artykułu, jednakże dla uświadomienia zakresu i czasochłonności badań ruchowych hamulca warto wspomnieć, że przykładowo dla najpopularniejszego spośród nowo produkowanych w Polsce elektrycznych zespołów trakcyjnych wyposażonych $\mathrm{w}$ hamulec pneumatyczny, elektropneumatyczny i elektrodynamiczny i tylko dla nastawienia hamulca „R” badania wykonywane są w trzech stanach obciążenia i dla pięciu prędkości poczatkowych z zakresu $30 \div 160 \mathrm{~km} / \mathrm{h}$. W czasie takich badań wykonuje się około 350 prób hamowania, a czas potrzebny na wykonanie tych prób to $15 \div$ 
- $B$ and $\lambda$ for all modes and types of braking these values are entered into the vehicle technical documentation

- maximum braking mass value $(\max B)$ that can be provided by the vehicle brake - this value is placed on the vehicle in the form of a standardized description

- the minimum guaranteed $\lambda$ value for the tested vehicle - this value is used at the testing stage to assess whether the requirements imposed on the brake system are met.

\section{METHODS OF DESCRIBING BRAKE EF- FICIENCY IN VEHICLES}

The size, color and location of the braking system descriptions on the vehicle, including the values related to the brake performance of rail vehicles, are standardized, and have been detailed in documents [4] $\div[6]$.

These provisions for freight wagons, passenger wagons and locomotives are very precise. Unfortunately, for descriptions of the traction unit brake, only general guidelines are provided.

As a result of this situation the owners of traction units have been left with a certain degree of "creative freedom" with regards to vehicle labeling. Currently, many different methods of describing the brake performance can be found. A few examples are shown in the following figures:

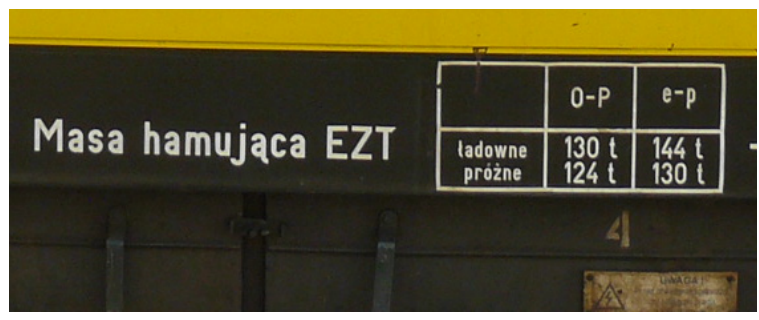

Fig. 1. Description of brake performance on a classic, not upgraded EN57

Rys. 1. Opis skuteczności hamulca na przykładzie klasycznego, nie modernizowanego ezt EN57

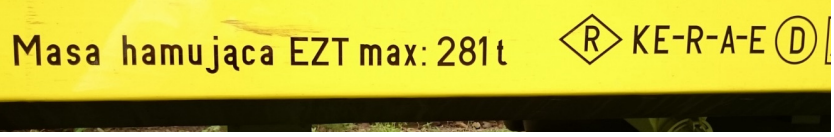

Fig. 3. Description of brake performance on an ezt type 31WE Rys. 3. Opis skuteczności hamulca na przykładzie ezt typu $31 \mathrm{WE}$

\section{DISADVANTAGES OF TRADITIONAL ME- THODS OF ASSESSING THE BRAKE PER- FORMANCE}

As mentioned above, before safely transporting a train through a railway section, its braking mass percentage (the so-called "real percentage of braking mass") should be determined and compared with the percentage of braking mass required for the given
20 dni roboczych.

Efektem badań jest uzyskanie wartości:

- $B$ i $\lambda$ dla wszystkich trybów i rodzajów hamowania - wartości te wprowadzane są do dokumentacji technicznej pojazdu

- maksymalnej wartości masy hamującej ( $\max B)$ jaką może zapewnić hamulec pojazdu - wartość ta $\mathrm{w}$ formie znormalizowanego opisu umieszczana jest na pojeździe

- minimalnej gwarantowanej dla badanego pojazdu wartości $\lambda$ - wartość ta służy na etapie badań do oceny spełnienia wymagań stawianych układowi hamulcowemu.

\section{SPOSOBY OPISU SKUTECZNOŚCI HA-} MULCA NA POJAZDACH

Rozmiary, kolor i miejsce umieszczenia na pojeździe opisów dotyczących systemu hamulcowego, w tym również wartości dotyczących skuteczności hamulca pojazdów szynowych, są znormalizowane, a szczegóły zawarto m.in. w dokumentach [4] $\div$ [6].

Przepisy te w odniesieniu do wagonów towarowych, pasażerskich i lokomotyw są bardzo precyzyjne, a dla opisów hamulca zespołów trakcyjnych zawierają niestety tylko ogólne wytyczne.

Skutkiem takiego stanu rzeczy jest pozostawienie właścicielom zespołów trakcyjnych pewnej ,swobody działania" w zakresie oznakowania pojazdów. Obecnie można spotkać różne metody opisu skuteczności hamulca. Kilka przykładów przedstawiono na poniższych rysunkach:

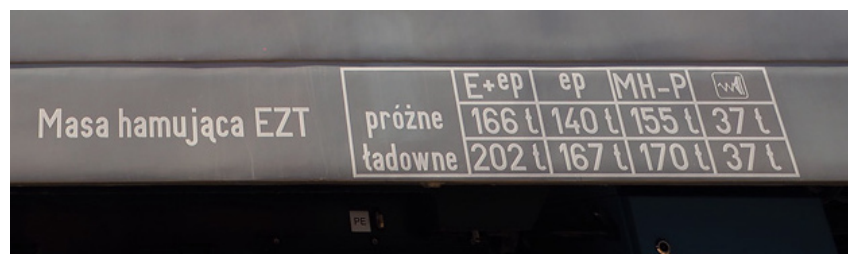

Fig. 2. Description of brake performance on a modernized EN57 model

Rys. 2. Opis skuteczności hamulca na przykładzie zmodernizowanego ezt EN57

\section{WADY TRADYCYJNYCH METOD OCENY SKUTECZNOŚCI HAMULCA}

Jak wspomniano wyżej przed bezpiecznym wyprawieniem pociagu na szlak należy określić jego procent masy hamującej (tzw. „rzeczywisty procent masy hamującej”) i porównać go z procentem masy hamującej wymaganym dla szlaku, na który wyprawiany jest pociąg.

Zgodnie $\mathrm{z}$ obecnie przyjętą praktyką skuteczność hamulca zespołu trakcyjnego oceniana jest za pomoca umieszczonych na pojeździe opisów zawierających wartości mas hamujących.

A. Dla klasycznych i części modernizowanych ezt EN57 przyjęto zgodnie $\mathrm{z}$ wieloletnią praktyką opis $\mathrm{w}$ postaci tabeli zawierającej wartości mas hamujących dla pojazdu w stanie ,próżnym” i 
route on which the train is to travel.

In accordance with the current practice, the trainset brake performance is assessed using descriptions containing the values of braking masses placed on the vehicles it is made up of.

A. For the classic and parts of the modernized ezt EN57, information was described in the form of a table containing the values of braking masses for the vehicle in "empty" and "loaded" state separately for the UIC pneumatic and electropneumatic brake (Fig. 1 and Fig. 2).

Calculation of the ezt brake performance, expressed in braking mass percentage, takes place in accordance with the algorithm shown in Figure 4.

The disadvantages of this method for assessing brake performance are:

-the possibility of precise and real-world braking mass percentage calculations only for an empty ezt

-the need to use substitute methods of calculating the brake performance for partially and the heavily loaded ezt, with the result being only approximate

- a misleading form of brake performance description (suggesting only a 2-step adjustment of brake performance to ezt load level while the adaptation is in reality infinitely variable).

B. For vehicles produced today as well as some of the modernized vehicles (including 31WE type and some of the upgraded EN57), a principle was adopted where only the maximum braking mass value would be placed on the vehicle (Figure 3).

Braking mass percentage calculation (and thus the ezt brake performance) takes place in this case in accordance with the algorithm described in Figure 5.

The disadvantages of this method for assessing brake performance are:

- the possibility of precise and real-world braking mass percentage calculations ONLY for an empty ezt

- the ability to precisely calculate the braking mass percentage when fully loaded, leaving uncertainty regarding the actual vehicle load state and the actual brake performance

- the need to use substitute methods of calculating the brake performance for partially loaded ezt, with the result being only approximate,

- it is not possible to use the "R $+\mathrm{Mg}$ ” brake setting. „ładownym” oddzielnie dla hamulca pneumatycznego UIC oraz elektropneumatycznego (rys. 1 oraz rys. 2).

Obliczenia skuteczności hamulca ezt, wyrażonej za pomoca procentu masy hamującej, odbywają się zgodnie $\mathrm{z}$ algorytmem przedstawionym na rys. 4.

Wadami tej metody oceny skuteczności hamulca sa:

- możliwość precyzyjnego i zgodnego ze stanem rzeczywistym obliczenia procentu masy hamujące tylko dla próżnego ezt

- konieczność stosowania zastępczych metod obliczeń skuteczności dla częściowo i maksymalnie obciążonego ezt, przy czym uzyskiwany wynik tylko przybliżony

- wprowadzająca w błąd forma opisu skuteczności hamulca (sugerująca tylko 2stopniowe dostosowanie skuteczności hamulca do obciążenia ezt podczas gdy dostosowanie jest bezstopniowe).

A. Dla współcześnie produkowanych pojazdów i niektórych modernizowanych (m.in. ezt typu 31WE i część modernizowanych ezt EN57) przyjęto zasadę umieszczania na pojeździe tylko wartości maksymalnej masy hamującej (rys. 3).

Obliczenia procentu masy hamującej (a więc skuteczności hamulca ezt) odbywają się w tym przypadku zgodnie $\mathrm{z}$ algorytmem przedstawionym na rys. 5.

Wadami takiej metody oceny skuteczności hamulca są:

- możliwość precyzyjnego i zgodnego ze stanem rzeczywistym obliczenia procentu masy hamujące tylko dla próżnego ezt

- możliwość precyzyjnego obliczenia procentu masy hamującej w stanie maksymalnie obciążonym, przy pozostawieniu wątpliwości co do rzeczywistego obciążenia pojazdu i rzeczywistej skuteczności hamulca

- konieczność stosowania zastępczych metod obliczeń skuteczności dla częściowo obciążonego ezt, (uzyskiwany wynik jest tylko przybliżony)

- brak możliwości zastosowania dla nastawienia hamulca „, $\mathrm{R}+\mathrm{Mg}$ ”.

\section{NOWA METODA OCENY SKUTECZNO-} ŚCI HAMULCA - PROPOZYCJA IK

Analiza dotychczas stosowanych metod obliczania i oceny skuteczności hamulca zespołów trakcyjnych oraz związanych z nimi sposobów opisywania skuteczności hamulca na pojazdach wykazała szereg wad 


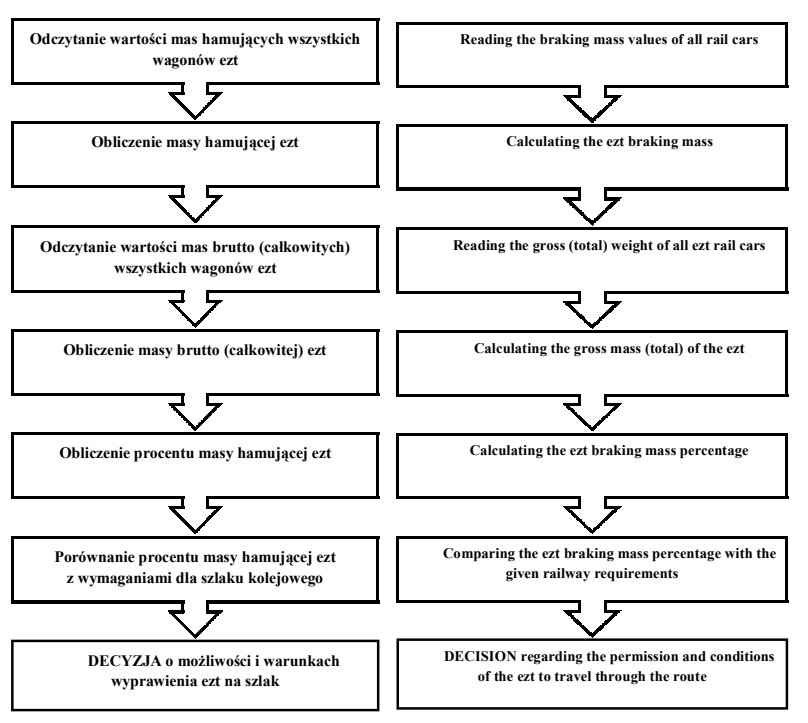

Fig. 4. Calculation algorithm and brake performance evaluation of the trainset to describe braking masses in the form of a table.

Rys. 4. Algorytm obliczeń i oceny skuteczności hamulca zespołu trakcyjnego dla opisu mas hamujących w postaci tabeli.

\section{A NEW METHOD FOR THE AS- SESSMENT OF BRAKE PERFORM- ANCE - A PROPOSAL BY THE RAIL INSTITUTE}

Analysis of the methods used to calculate and evaluate the brake performance of the traction unit and related methods of describing the brake performance in vehicles has revealed a number of disadvantages in these methods. It is concerning that none of the currently used methods allow to precisely calculate the ezt brake performance for partially loaded vehicles, i.e. in which the vehicles are most often used.

Due to the issues discussed above, a new and original concept of description and calculations of the effectiveness of the brake of traction units was developed at the Brake Workshop of the Railway Institute (later in the article abbreviated as "IK") in Krakow.

The goals of developing a new concept were:

- unification of the method used to describe brake performance of traction units

- simplifying the brake performance assessment procedure

- obtaining a method that can be used for each trainset load state without needing to rely on replacement methods.

The essence and novelty of the method developed by IK is changing the existing method of brake performance assessment for traction units - this description should include:

- value of maximum trainset braking mass (expressed in tons) - in accordance with the currently used method described in point 6 , lit. B and shown in Fig. 3

- the minimum guaranteed braking mass percentage value for the trainset (expressed as a

POJAZDY SZYNOWE / RAIL VEHICLES NR 2/2019

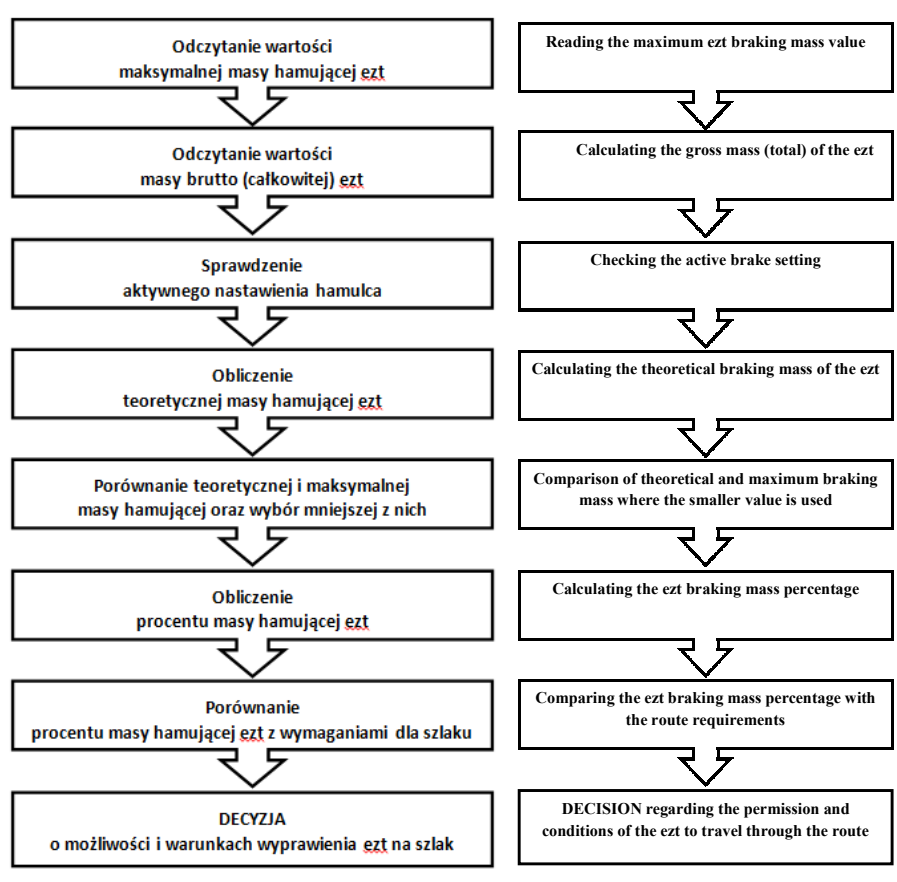

Fig. 5. Calculation algorithm and evaluation of the traction unit brake performance to describe it in the form of the maximum braking mass value.

Rys. 5. Algorytm obliczeń i oceny skuteczności hamulca zespołu trakcyjnego dla opisu w postaci wartości maksymalnej masy hamującej.

tych metod. Niepokojącym jest fakt, że żadna z obecnie stosowanych metod nie pozwala precyzyjnie obliczyć skuteczności hamulca ezt $\mathrm{w}$ stanie częściowo obciążonym, czyli w takim w jakim pojazdy te najczęściej są eksploatowane.

W związku z powyższym w Instytucie Kolejnictwa (w dalszej części artykułu w skrócie „IK”) w Pracowni Hamulców w Krakowie opracowano nową, oryginalną koncepcję opisu i obliczeń skuteczności hamulca zespołów trakcyjnych.

Celami opracowania nowej koncepcji były:

- ujednolicenie sposobu opisu skuteczności hamulca na zespołach trakcyjnych

- uproszczenie procedury oceny skuteczności hamulca

- możliwość zastosowania do każdego stanu obciążenia zespołu trakcyjnego bez konieczności używania metod zastępczych.

Istotą i nowością opracowanej w IK metody jest zmiana dotychczasowego sposobu opisu skuteczności hamulca na zespołach trakcyjnych - opis ten powinien zawierać:

- wartość maksymalnej masy hamującej zespołu trakcyjnego (wyrażoną w tonach) - zgodnie $\mathrm{z}$ obecnie już stosowanym sposobem opisanym $\mathrm{w}$ pkt. 6 , lit. B i przedstawionym na rys. 3

- wartość minimalnego gwarantowanego procentu masy hamującej zespołu trakcyjnego (wyrażoną w procentach i zamieszczoną w nawiasie) - co jest nowościa proponowanej metody. 
percentage and in brackets) - which is the novelty of the proposed method.

In accordance with the guidelines of the new IK method described above, the description of the trainset brake performance should correspond to the example shown in Figure 6.

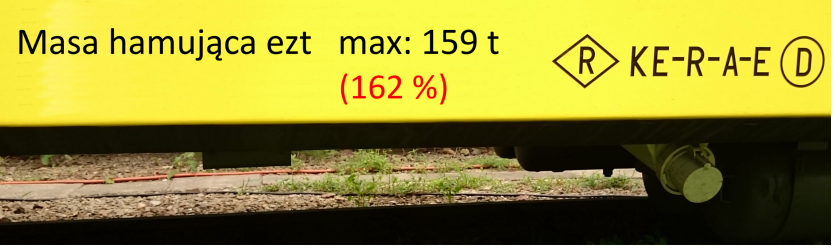

Fig. 6. An example of the braking performance description proposed by IK Kraków in the form of maximum braking mass and additionally the minimum guaranteed braking mass percentage (value in red font and placed in brackets).

Rys. 6. Przykład proponowanego przez IK Kraków opisu skuteczności hamulca

Fig. 7 presents the algorithm for brake performance assessment of the traction unit according to the new method developed by IK.

Tables $1 \div 3$ compare the possibilities of assessing the brake performance of traction units for both currently used methods and for the new method proposed by IK.

Table 1.Data and results summary showing the possibility of assessing a traction unit brake performance and describing braking mass on the vehicle in the form of a table.

Tabela 1. Zestawienie danych i wyników obrazujące możliwość oceny skuteczności hamulca zespołu trakcyjnego dla opisu mas hamujących na pojeździe w postaci tabeli
Opis skuteczności hamulca zespołu trakcyjnego zgodny z opisanymi wyżej wytycznymi nowej metody IK powinien odpowiadać przykładowi proponowanemu przez IK Kraków opisu skuteczności hamulca $\mathrm{w}$ postaci wartości maksymalnej masy hamującej i dodatkowo minimalnego gwarantowanego procentu masy hamującej (wartość opisana czerwoną czcionką i umieszczona $\mathrm{w}$ nawiasie), przedstawionemu na rys. 6.

Na rys. 7 przedstawiono algorytm oceny skuteczności hamulca zespołu trakcyjnego wg nowej metody opracowanej w IK.
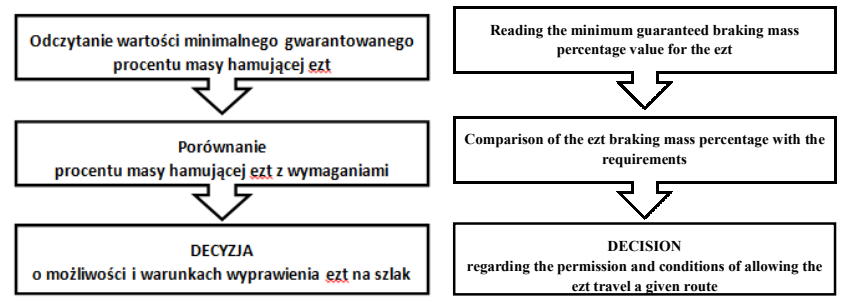

Fig. 7. Algorithm to evaluate the brake performance of the traction unit according to the new method based on the concept by IK.

Rys. 7. Algorytm oceny skuteczności hamulca zespołu trakcyjnego wg nowej koncepcji IK

W tabelach $1 \div 3$ porównano możliwości oceny skuteczności hamulca zespołów trakcyjnych dla obydwu stosowanych obecnie metod i dla nowej metody proponowanej przez IK.

\begin{tabular}{|c|c|c|c|c|}
\hline & \multicolumn{3}{|c|}{ Load state: } & \multirow[b]{2}{*}{ Comments } \\
\hline & empty & partially loaded & fully loaded & \\
\hline $\mathbf{m}$ & $126.5 \mathrm{t}$ & no data & no data & \multirow{2}{*}{ values found inscribed on the vehicle } \\
\hline B & $124.0 \mathrm{t}$ & no data & $130.0 \mathrm{t}$ & \\
\hline$\lambda$ & $98 \%$ & $\begin{array}{l}\text { impossible to } \\
\text { calculate }\end{array}$ & $\begin{array}{l}\text { impossible to } \\
\text { calculate }\end{array}$ & $\begin{array}{l}\text { value calculated based on the read values of } m \\
\text { and } B\end{array}$ \\
\hline
\end{tabular}

\begin{tabular}{|c|c|c|c|c|}
\hline & \multicolumn{3}{|c|}{ Stan obciążenia: } & \multirow[b]{2}{*}{ Uwagi } \\
\hline & próżny & $\begin{array}{l}\text { częściowo } \\
\text { obciążony }\end{array}$ & $\begin{array}{l}\text { maksymalnie } \\
\text { obciążony }\end{array}$ & \\
\hline m & $126,5 \mathrm{t}$ & brak danych & brak danych & \multirow{2}{*}{$\begin{array}{l}\text { wartości odczytane } \\
\text { z opisów na pojeździe }\end{array}$} \\
\hline B & $124,0 \mathrm{t}$ & brak danych & $130,0 \mathrm{t}$ & \\
\hline$\lambda$ & $98 \%$ & $\begin{array}{l}\text { obliczenie nie- } \\
\text { możliwe }\end{array}$ & $\begin{array}{l}\text { obliczenie nie- } \\
\text { możliwe }\end{array}$ & $\begin{array}{l}\text { wartość obliczona na podstawie odczytanych } m \\
\text { i } B\end{array}$ \\
\hline
\end{tabular}

Note: $\quad$ calculation of the actual brake performance is possible only for an empty vehicle, in other load states it is necessary to use substitute methods (approximate).

Uwagi: $\quad$ obliczenie rzeczywistej skuteczności hamulca możliwe tylko dla pojazdu próżnego, w innych stanach obciażenia konieczne jest stosowanie metod zastepczych (przybliżonych). 
Table 2. Data and results summary showing the brake performance assessment possibility of the traction unit to describe the vehicle braking mass as a maximum value.

Tabela 2. Zestawienie danych i wyników obrazujące możliwość oceny skuteczności hamulca zespołu trakcyjnego dla opisu mas hamujących na pojeździe w postaci wartości maksymalnej

\begin{tabular}{|c|c|c|c|c|}
\hline & \multicolumn{3}{|c|}{ Load state: } & \multirow[b]{2}{*}{ Comments } \\
\hline & empty & partially loaded & fully loaded & \\
\hline m & $136.0 \mathrm{t}$ & no data & $172.0 \mathrm{t}$ & values found inscribed on the vehicle \\
\hline B & $204.0 \mathrm{t}$ & no data & $258.0 \mathrm{t}$ & \multirow{2}{*}{$\begin{array}{l}\text { value calculated based on the read values of } \\
m \text { and the brake settings }\end{array}$} \\
\hline$\lambda$ & $150 \%$ & $\begin{array}{l}\text { impossible to } \\
\text { calculate }\end{array}$ & $150 \%$ & \\
\hline
\end{tabular}

\begin{tabular}{|c|c|c|c|c|}
\hline & \multicolumn{3}{|c|}{ Stan obciążenia: } & \multirow[b]{2}{*}{ Uwagi } \\
\hline & próżny & $\begin{array}{l}\text { częściowo } \\
\text { obciążony }\end{array}$ & $\begin{array}{l}\text { maksymalnie } \\
\text { obciążony }\end{array}$ & \\
\hline m & $136,0 \mathrm{t}$ & brak danych & $172,0 \mathrm{t}$ & wartość odczytana z opisu na pojeździe \\
\hline B & $204,0 \mathrm{t}$ & brak danych & $258,0 \mathrm{t}$ & \multirow{2}{*}{$\begin{array}{l}\text { wartości obliczone na podstawie odczytanej } \\
\qquad m \text { i nastawienia hamulca }\end{array}$} \\
\hline$\lambda$ & $150 \%$ & $\begin{array}{l}\text { obliczenie nie- } \\
\text { możliwe }\end{array}$ & $150 \%$ & \\
\hline
\end{tabular}

Note: $\quad$ calculation of the actual brake performance is possible only for an empty vehicle or when fully loaded, in partial load states it is necessary to use substitute methods (approximate).

Uwagi: $\quad$ obliczenie rzeczywistej skuteczności hamulca możliwe tylko dla pojazdu próżnego i maksymalnie obciażonego, dla pojazdu częściowo obciqżonego konieczne jest stosowanie metod zastępczych (przybliżonych).

Table 3. Data and results summary showing the brake performance assessment possibility of the traction unit to describe the vehicle's parameters according to the new method proposed by IK.

Tabela 3. Zestawienie danych i wyników obrazujące możliwość oceny skuteczności hamulca zespołu trakcyjnego dla opisu na pojeździe wg nowej metody proponowanej przez IK.

\begin{tabular}{|c|c|c|c|c|}
\hline & \multicolumn{3}{|c|}{ Load state: } & \multirow[b]{2}{*}{ Comments } \\
\hline & empty & partially loaded & fully loaded & \\
\hline $\mathbf{m}$ & \multirow{2}{*}{\multicolumn{3}{|c|}{ values not necessary }} & \multirow{2}{*}{$\begin{array}{l}\text { these values are not used to assess the brake } \\
\text { performance in the new method proposed by IK }\end{array}$} \\
\hline B & & & & \\
\hline$\lambda$ & \multicolumn{3}{|c|}{$162 \%$} & values found inscribed on the vehicle \\
\hline
\end{tabular}

\begin{tabular}{|c|c|c|c|c|}
\hline & \multicolumn{3}{|c|}{ Stan obciążenia: } & \multirow[b]{2}{*}{ Uwagi } \\
\hline & próżny & $\begin{array}{l}\text { czę́ściowo } \\
\text { obciążony }\end{array}$ & $\begin{array}{l}\text { maksymalnie } \\
\text { obciążony }\end{array}$ & \\
\hline $\mathbf{m}$ & \multirow{2}{*}{\multicolumn{3}{|c|}{ wartości nie wymagane }} & $\begin{array}{l}\text { w nowej metodzie proponowanej przez IK war- } \\
\text { tości te nie są stosowane w ocenie skuteczności }\end{array}$ \\
\hline B & & & & hamulca \\
\hline$\lambda$ & \multicolumn{3}{|c|}{$162 \%$} & wartość odczytana z opisu na pojeździe \\
\hline
\end{tabular}

Note: $\quad$ no need to calculate, the value $\lambda$ marked on the vehicle corresponds to the minimum guaranteed brake performance for EVERY load condition.

Uwagi: $\quad$ brak konieczności wykonywania obliczeń, odczytana wartość $\lambda$ odpowiada minimalnej gwarantowanej skuteczności hamulca dla KAŻDEGO stanu obciqżenia. 
Based on the analysis of Figs. 4, 5 and 7 as well as tables $1 \div 3$, it can be stated that the new method of describing the vehicle and the new method of brake performance assessment of the traction unit according to the IK's proposal allow:

- to simplify the brake performance assessment method - the new IK method algorithm includes 3 steps (previous methods required 7 or 8 steps respectively)

- to eliminate the need for any calculations (the value is read directly from the markings on the vehicle - see Figure 6), which reduces the risk of error

- to properly and accurately assess the brake performance for each vehicle load state (without needing to use any substitute methods)

\section{CONCLUSIONS}

The new method of assessing traction vehicle brake performance proposed by the Railway Institute simplifies the process of brake performance evaluation and does not require any additional tests to be carried out on vehicles that were approved for use in recent years.

The advantages of the method described in this article proposed by IK include:

- can be used for a vehicle in any load state

- can be used with any brake setting

- the braking mass percentage of the vehicle corresponds to the actual value

- minimizing the possibility of making a calculation error for the braking mass percentage (practically no calculations are required)

- avoiding situations where the brake performance can be underestimated.

It should be noted that the use of this method is limited to traction units with automatic continuous adjustment of the braking force relative to the load.

In order for this method to be used in practice, it is necessary to:

- modify the brake performance descriptions on vehicles

- amending the regulations regarding the brake performance assessment of traction units

- training of personnel assessing brake performance.
W oparciu o analize (rys. 4, 5 i 7 oraz tabele $1 \div 3$ ) można zauważyć, że nowy sposób opisu na pojeździe i nowa metoda oceny skuteczności hamulca zespołu trakcyjnego wg propozycji IK pozwalają:

- uprościć sposób oceny skuteczności hamulca algorytm nowej metody IK obejmuje 3 czynności (dotychczasowe metody wymagały odpowiednio 7 lub 8 czynności)

- wyeliminować konieczność jakichkolwiek obliczeń (wartość odczytywana jest bezpośrednio z opisu na pojeździe - patrz rys. 6), co pozwala obniżyć ryzyko popełnienia błędu

- prawidłowo i dokładnie ocenić skuteczność hamulca dla każdego stanu obciążenia (bez konieczności stosowania jakichkolwiek metod zastępczych)

\section{PODSUMOWANIE}

Proponowana przez Instytut Kolejnictwa nowa metoda oceny skuteczności hamulca zespołów trakcyjnych pozwala uprościć proces oceny skuteczności hamulca i nie wymaga wykonywania żadnych dodatkowych badań dla pojazdów, które były dopuszczane do eksploatacji w ostatnich latach.

Zaletami opisanej w niniejszym artykule metody proponowanej przez IK są:

- możliwość zastosowania dla każdego stanu obciążenia pojazdu

- możliwość zastosowania dla każdego nastawienia hamulca

- wartość procentu masy hamującej pojazdu odpowiada rzeczywistej wartości

- minimalizacja możliwości popełnienia błędu w obliczaniu procentu masy hamującej (praktycznie nie są wymagane żadne obliczenia)

- uniknięcie sytuacji, w których skuteczność hamulca może być niedoszacowana.

Należy przy tym pamiętać, że zastosowanie tej metody jest ograniczone do zespołów trakcyjnych z samoczynnym ciagłym dostosowaniem siły hamującej do obciążenia.

Aby metoda ta mogła być stosowana $\mathrm{w}$ praktyce konieczne jest:

- zmodyfikowanie opisów skuteczności hamulca na pojazdach,

- znowelizowanie przepisów dotyczących oceny skuteczności hamulca zespołów trakcyjnych,

- przeprowadzenie szkoleń personelu dokonującego oceny skuteczności hamulca. 


\section{Bibliography / Bibliografia}

[1] UIC 544-1, Ed. no.6, October 2014 Brakes - Braking performance.

[2] Rozporzqdzenie Komisji (UE) nr 1302/2014 z dnia 18 listopada 2014 r. w sprawie technicznej specyfikacji interoperacyjności odnoszacej się do podsystemu „,Tabor - lokomotywy i tabor pasażerski” systemu kolei w Unii Europejskiej,Bruksela, 18 listopada 2014

[3] PN-EN 16185-2:2015-02 Kolejnictwo - Systemy hamulcowe wieloczłonowych zespołów trakcyjnych. Część 2: Metody badań.

[4] UIC 545 Brakes - Inscriptions, marks and signs, Edition no.10, December 2014.

[5] PN-EN 15877-1: 2012 Kolejnictwo - Znakowanie na pojazdach kolejowych-Czesść 1: Wagony towarowe.

[6] PN-EN 15877-2: 2013-12 Kolejnictwo - Znaki na pojazdach kolejowych - Część 2: Znaki zewnętrzne na wagonach pasażerskich, pojazdach trakcyjnych, lokomotywach i na maszynach do prac torowych. 